\title{
Pengukuran Indeks Keberlanjutan Industri Gula
}

\author{
Measurement of Sugar Industry Sustainability Index \\ Hartrisari Hardjomidjojo $^{1 *}$, Sapta Raharja ${ }^{1}$, dan Muti'atul Chosyi'ah ${ }^{1}$ \\ ${ }^{1}$ Departemen Teknologi Industri Pertanian, Fakultas Teknologi Pertanian Institut Pertanian Bogor \\ Jl. Kamper Kampus IPB Dramaga, Bogor 16680 \\ Email: sari@biotrop.org
}

\begin{abstract}
ABSTRAK
Gula merupakan salah satu komoditas penting dari sektor pertanian, khususnya di sektor perkebunan Indonesia. Jumlah penduduk Indonesia yang besarmenyebabkan konsumsi gula tinggi setiap tahun, namun kondisi ini tidak didukung oleh produktivitas gula nasional yang tinggi sehingga terjadi impor gula rafinasi. Tujuan penelitian ini mengukur indeks keberlanjutan industri gula untuk meningkatkan strategi perbaikan prioritas yang harus dilakukan. Penelitian ini menggunakan multidimensi Scalling (MDS) dengan delapan dimensi dan 34 atribut. Analisis dilakukan untuk tahun 2012-2014 pada industri gula yang diambil sebagai contoh pada penelitian ini. Kinerja secara berturutan dianggap baik, namun, dimensi material harus menjadi perhatian dalam perbaikan di masa depan.
\end{abstract}

Kata kunci: MDS, indeks keberlanjutan, industri gula

\begin{abstract}
Sugar is one of the potential plantation commodities from the agricultural sector in Indonesia. The huge population of Indonesia is causing high sugar consumption quantity every year. This condition is not supported by the national sugar high productivity, resulting in import of refined sugar. The purpose of this study is to measure the sugar industries' sustainability indexes to increase the improvement strategies priority. This study uses a Multidimensional Scaling (MDS) method with eight dimensions that consist of thirty-four attributes. The analysis is performed for two years, from 2012-2014 in the sugar industry as a case study in this study. Successive performance is considered in "good" condition, however the material dimension should be the priority concern in future improvement.
\end{abstract}

Key words: MDS, sugar industries, sustainability index

\section{PENDAHULUAN}

Gula merupakan salah satu komoditas yang penting dalam kehidupan. Negara dengan jumlah penduduk keempat terbesar di dunia, telah menjadikan Indonesia menjadi salah satu konsumen gula terbesar di dunia. Menurut data Direktur Jendral Perkebunan (2013), kebutuhan gula nasional meningkat 3\% tiap tahunnya. Hal ini belum diimbangi dengan meningkatnya produksi gula nasional sehingga untuk menutupi kebutuhan gula tersebut tersebut pemerintah melakukan impor gula. Kondisi industri gula nasional saat ini cenderung menurun. Hal ini terlihat dari penurunan rendemen dan produktivitas gula. Menurut Asosiasi Gula Indonesia (2013), pada tahun 2013 rendemen gula $8.13 \%$ dengan produksi gula 2.59 juta ton, mengalami penurunan menjadi $7.20 \%$ dan 2.39 juta ton. Hal tersebut disebabkan oleh permasalahan di tingkat hulu (usaha tani), hilir (industri gula), bidang perdagangan, harga dan distribusi gula. Data konsumsi gula per kapita di Indonesia 11.31 kilogram/orang/tahun. Dengan jumlah penduduk Indonesia 245.8 juta jiwa (data tahun 2014), maka total kebutuhan gula nasional menjadi 2.76 juta ton. Produksi gula nasional yang hanya sebesar 2.57 juta ton. Dalam rangka menutupi kekurangan tersebut pemerintah melakukan impor gula rafinasi 3.5 juta ton. Hal ini

\footnotetext{
*) Korespondensi:

Departemen Teknologi Industri Pertanian, Fateta, Jl. Kamper Kampus IPB Dramaga, Bogor 16680; email: sari@biotrop.org
} 
dirasakan berlebih, melihat kekurangan kebutuhan gula hanya 0.19 juta ton. Kelebihan gula ini menyebabkan gula rafinasi masuk ke pasar tradisional yang seharusnya digunakan untuk industri. Gula rafinasi memiliki harga relatif murah dibandingkan dengan gula kristal putih.

Penelitian ini bertujuan mengukur indeks keberlanjutan industri gula dan menentukan strategi untuk meningkatkan kinerja. Industri gula contoh merupakan industri yang berada di bawah naungan PT Rajawali Nusantara Indonesia.

\section{METODE PENELITIAN}

Pengukuran indeks keberlanjutan pada penelitian ini menggunakan metode RAPFISH (Picher dan Preiskhot, 2001) yang dimodifikasi. RAPFISH merupakan teknik pengukuran cepat berbasis informasi multi disiplin untuk mengevaluasi keberlanjutan kondisi perikanan. Dalam penelitian ini, pendekatan yang sama akan digunakan untuk mengukur indeks keberlanjutan industri gula.

Dalam penggunaannya, RAPFISH cukup sederhana, menggunakan cara yang mudah untuk memberikan penilaian pada atribut yang dipilih agar menghasilkan penilaian yang cepat, tidak mahal dan mendeskripsikan status perikanan dari sisi multi dimensional dalam bentuk indeks keberlanjutan (Pitcher et al, 2013). Dalam penggunaan RAPFISH, arti kata keberlanjutan didefinisikan secara kuantitaif sebagai kumpulan dari kriteria tertentu yang direpresentasikan sebagai nilai skor dari atribut. Ordinasi multivariat dari skor tersebut akan menunjukkan status keberlanjutan dari kondisi perikanan yang terdiri dari berbagai dimensi seperti ekologi, teknologi. ekonomi, sosial dan etika.

Pada penelitian ini, karena topik yang dikaji adalah industri, maka kajian dimensi dilihat dari delapan dimensi yang biasa dikenal dengan 7M1E yaitu: Men, Money, Machine, Method, Materials, Market, Management dan Environment. Ordinasi atribut akan dilaksanakan menggunakan skala mutidimensional (MDS) dan diikuti dengan pengukuran skala dan rotasi. Ordinasi diposisikan sebagai dasar yang merepresentasikan titik referensi yang akan disimulasi untuk mendapatkan kemungkinan nilai terendah dan terbaik dari posisi kinerja industri gula berdasarkan skor ekstrim dari atributnya.

Simulasi Monte Carlo digunakan untuk mengestimasi galat dan leverage atau faktor pengungkit dari tiap atribut dapat diestimasi melalui beberapa cara. Hasil akan direpresentasikan dalam skala $0-100 \%$ dan skor dari dimensi direpresentasikan dalam bentuk diagram layang untuk membantu pengertian komprehensif dari grafik. Validasi dari metode ini menggunakan data hasil pengukuran (survei). Gambar 1 menunjukkan tahapan dalam metode ini.

Berdasarkan wawancara dengan pakar dari industri gula yang digunakan sebagai contoh

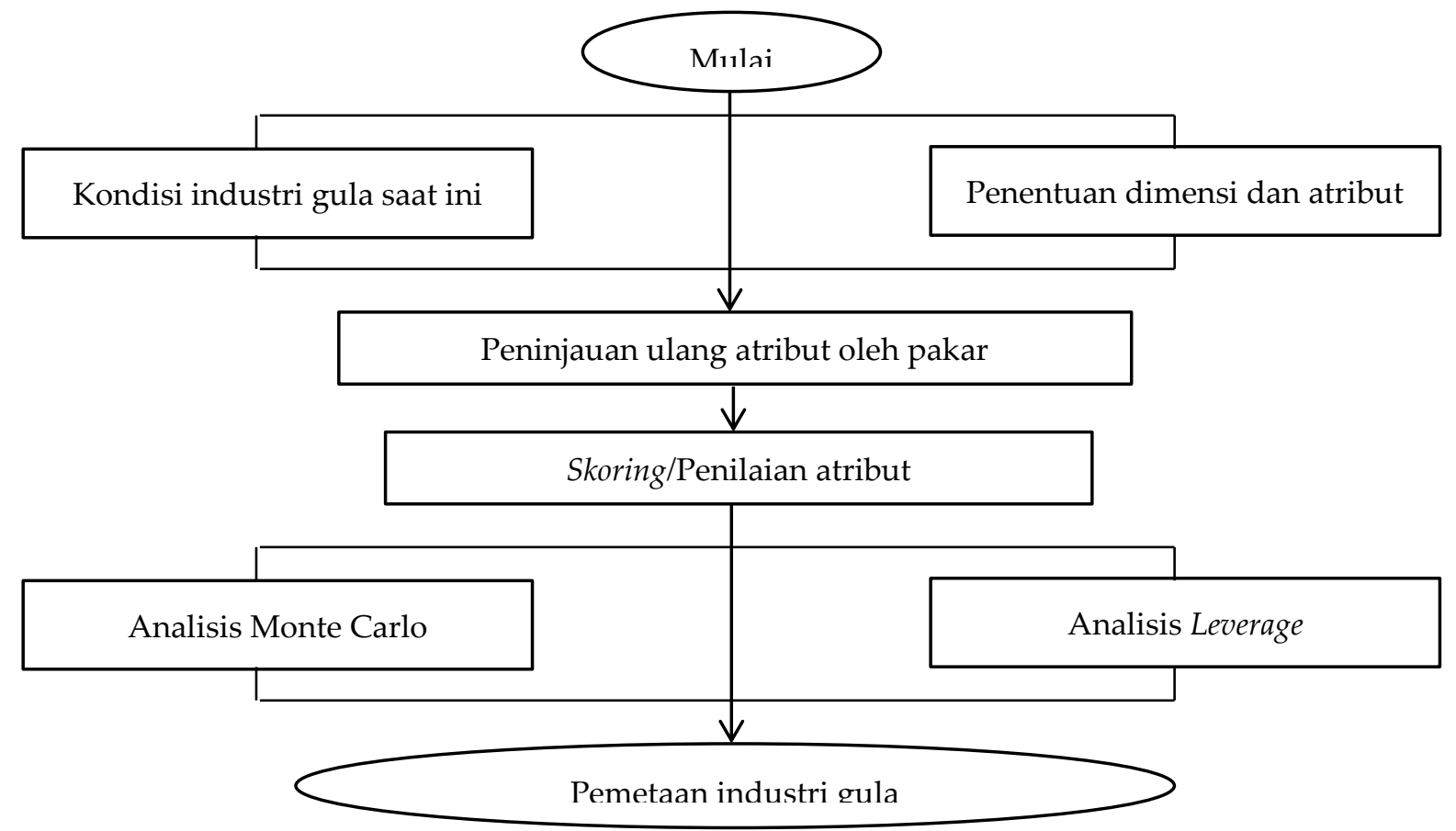

Gambar 1. Tahapan yang digunakan dalam penelitian 
Tabel 1. Atribut dan indikator dimensi bahan

\begin{tabular}{|c|c|c|c|c|}
\hline ATRIBUT & SKOR & BAIK & BURUK & INDIKATOR \\
\hline a. Jumlah tebu & $0 ; 1 ; 2$ & 2 & 0 & $\begin{array}{l}\text { Perbandingan tebu yang tersedia } \\
\text { dengan tebu yang dibutuhkan } \\
\text { (0) } \leq 85 \% \\
\text { (1) } 85-95 \% \\
\text { (2) } \geq 95 \%\end{array}$ \\
\hline $\begin{array}{l}\text { b. Jumlah kotoran } \\
\text { pada tebu }\end{array}$ & $0 ; 1 ; 2$ & 2 & 0 & $\begin{array}{l}\text { (0) } \geq 5 \% \text { dari bobot tebu } \\
\text { (1) } 5-3 \% \text { dari bobot tebu } \\
\text { (2) } \leq 3 \% \text { dari bobot tebu }\end{array}$ \\
\hline c. Mutu tebu & $0 ; 1 ; 2$ & 2 & 0 & $\begin{array}{l}\text { (0) } \text { pol tebu } \leq 9 \% \\
\text { (1) } \text { pol tebu } 9-11 \% \\
\text { (2) } \text { pol tebu } \geq 11 \%\end{array}$ \\
\hline d. Produktivitas Tebu & $0 ; 1 ; 2$ & 2 & 0 & $\begin{array}{l}\text { (0) } \leq 60 \text { ton/ha } \\
\text { (1) } 60-75 \text { ton/ha } \\
\text { (2) } 75 \text { ton/ha }\end{array}$ \\
\hline
\end{tabular}

penelitian didapatkan 34 atribut untuk kedelapan dimensi yang telah ditentukan sebelumnya. Dimensi material memiliki empat atribut, yaitu jumlah tebu, jumlah kotoran pada tebu, mutu tebu, dan produktivitas tebu. Tabel 1 menunjukkan contoh keempat atribut tersebut yang disertai dengan deskripsi dan nilai skornya.

Dimensi mesin memiliki lima atribut, yakni gula yang hilang dalam proses, overall recovery, kebutuhan energi mesin, usia mesin, dan kemajuan teknologi mesin. Terdapat empat atribut pada dimensi metode, yaitu kondisi infrastruktur, ketersediaan infrastuktur, perencanaan pola giling, penerapan keamanan dan keselamatan kerja (K3). Dimensi manusia memiliki empat atribut, yaitu kecukupan jumlah pekerja pabrik, ketersediaan pekerja pabrik, tingkat pendidikan pekerja, dan kemampuan/ kompetensi pekerja. Pada atribut manajemen terdapat tiga atribut yaitu hubungan dengan petani tebu binaan, hubungan dengan petani non binaan dan hubungan dengan lembaga formal. Dimensi ekonomi memiliki empat atribut yaitu rendemen gula (GKP), hablur gula, (BPP) gula, dan laba/return of invesment (ROI). Terdapat empat dimensi pada dimensi pasar, yaitu ketergantungan konsumen, daya saing dengan gula GKP lain, dukungan pasar dan kebijakan pasar. Dimensi lingkungan memiliki enam atribut, yaitu sifat limbah, kuantitas limbah, pengolahan limbah, pembuangan limbah, pengaruh limbah pada lingkungan dan pengawasan kondisi limbah. Hasil penilaian kinerja industri gula menggunakan metode Multidimentional Scalling (MDS) menunjukkan nilai sustainability index, $\mathrm{R}^{2}$ dan Stress untuk setiap dimensi. Skala nilai indeks mempunyai rentang $0 \%$ (buruk) sampai 100\% (baik) yang dikategorikan menjadi empat kategori seperti yang dimuat pada Tabel 2.

Tabel 2. Kategori status kinerja industri gula

\begin{tabular}{cc}
\hline Nilai indeks & Kategori \\
\hline$<25.00$ & Buruk \\
$25.00-49.99$ & Kurang \\
$50-74.99$ & Baik \\
$>75.00$ & Sangat Baik \\
\hline
\end{tabular}

Sumber: Kavanagh dan Pitcher (2004).

Nilai Stress menunjukkan keakuratan data. Stress dapat dikatakan baik, jika nilainya tidak lebih kecil dari $0.25(\mathrm{~S}<0.25)$. $\mathrm{R}^{2}$ menggambarkan keakuratan data dan perlu tidaknya penambahan atau pengurangan atribut dalam sebuah dimensi. $\mathrm{R}^{2}$ dapat dikatakan baik, jika nilainya lebih besar dari $0.80\left(R^{2}>0.80\right)$.

\section{HASIL DAN PEMBAHASAN}

Hasil analisis MDS untuk kinerja industri gula contoh pada tahun 2012 dapat dilihat pada Tabel 3. Pada Tabel 3 terlihat bahwa setiap dimensi untuk setiap tahunnya memiliki nilai Stress $<0.25$ dan nilai $R^{2}>0.80$. Hal ini menunjukkan bawa semua atribut untuk setiap dimensi telah menggambarkan kondisi kinerja industri gula yang sebenarnya dan tidak perlu dilakukan penambahan atau pengurangan jumlah atribut. Hasil analisis Monte Carlo dapat dilihat pada Tabel 4. 
Tabel 3. Hasil penilain industri gula yang diambil sebagai contoh pada penelitian ini

\begin{tabular}{lccc}
\hline Dimensi & $\begin{array}{c}\text { Nilai } \\
\text { indeks }\end{array}$ & Stress & $\mathbf{R}^{2}$ \\
\hline Material & 49.81 & 0.16 & 0.93 \\
Mesin & 85.64 & 0.15 & 0.94 \\
Metode & 69.94 & 0.16 & 0.93 \\
Manusia & 74.58 & 0.16 & 0.93 \\
Manajemen & 62.69 & 0.20 & 0.83 \\
Ekonomi & 66.95 & 0.17 & 0.93 \\
Pasar & 75.47 & 0.19 & 0.92 \\
Lingkungan & 85.12 & 0.14 & 0.93 \\
\hline
\end{tabular}

Tabel 4. Perbandingan nilai indeks MDS dengan analisis Monte Carlo tahun 2012

\begin{tabular}{lccc}
\hline Dimensi & $\begin{array}{c}\text { Nilai } \\
\text { Indeks } \\
(\mathrm{a})\end{array}$ & $\begin{array}{c}\text { Monte } \\
\text { Carlo } \\
(\mathrm{b})\end{array}$ & $\begin{array}{c}\text { Selisih (\%) } \\
(\mathrm{a}-\mathrm{b})\end{array}$ \\
\hline Material & 49.81 & 50.05 & 0.48 \\
Mesin & 85.64 & 83.50 & 2.50 \\
Metode & 69.94 & 68.51 & 2.04 \\
Manusia & 74.58 & 72.09 & 3.34 \\
Manajemen & 62.69 & 60.41 & 3.64 \\
Ekonomi & 66.95 & 65.83 & 1.68 \\
Pasar & 75.47 & 74.29 & 1.56 \\
Lingkungan & 85.12 & 81.83 & 3.29 \\
\hline
\end{tabular}

Hasil pada Tabel 4 menunjukkan bahwa selisih nilai indeks dengan nilai analisis Monte Carlo untuk setiap dimensi tidak lebih dari 5\%, sehingga dapat dikatakan bahwa nilai indeks kinerja industri gula PT $X$ valid dan memiliki random error relatif kecil.

Representasi dari nilai indeks digambarkan dalam diagram layang seperti pada Gambar 2. Berdasarkan Gambar 2 terlihat bahwa nilai indeks kinerja yang paling kecil adalah dimensi material dengan nilai indeks 49.81 dan dikategorikan dalam kinerja kurang. Analisis leverage dari dimensi material dapat dilihat pada Gambar 3.
Terlihat pada Gambar 3 bahwa faktor pengungkit yang paling sensitif pada dimensi material di tahun 2012 adalah jumlah tebu dan produktivitas tebu. Jumlah tebu berpengaruh $8.47 \%$ dan produktivitas tebu berpengaruh $8.40 \%$ dalam mengubah sustainability index dimensi material.

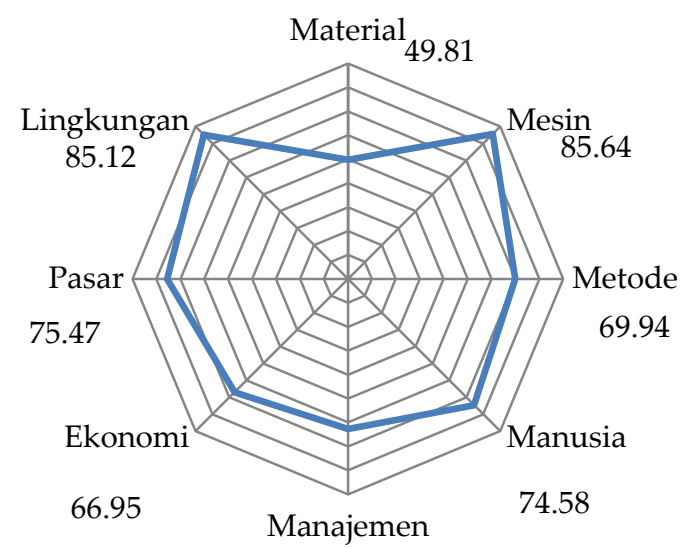

62.69

Keterangan:

Koordinat maksimum 100 (sangat baik)

Koordinat minimum 0 (sangat buruk)

Gambar 2. Diagram layang untuk kinerja industri gula pada penelitian di tahun 2012

Oleh karena itu untuk meningkatkan nilai sustainability index dimensi material perlu dilakukan peningkatkan produktivitas tebu dan jumlah pasokan tebu untuk masa giling tahun 2013. Salah satu cara peningkatkan produktivitas tebu penerapan program bongkar ratoon. Menurut Supriyati (2013), program bongkar ratoon dapat meningkatkan produktivitas tebu hampir 126\%. Untuk itu perlu dilakukan penataan varietas dengan varietas bibit unggul, agar produktivitas tebu maksimal.

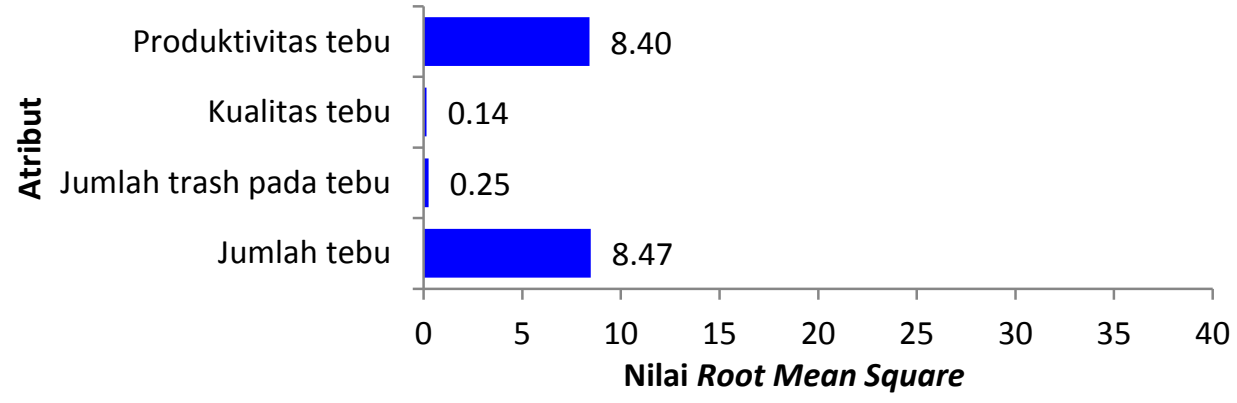

Gambar 3. Grafik analisis leverage dimensi material pada tahun 2012 
Selanjutnya dilakukan penilaian terhadap kinerja industri gula PT X pada tahun 2013 dengan cara dan analisis yang sama. Pada diagram layang (Gambar 4) terlihat bahwa dimensi material merupakan dimensi yang masih memiliki nilai indeks kinerja paling rendah (54.52). Apabila dibandingkan dengan nilai pada tahun 2012 maka terlihat terjadi peningkatan. Pada analisis sebelumnya, dinyatakan bahwa perlu peningkatan pasokan tebu untuk meningkatkan nilai sustainability index dimensi material. Hal tersebut telah dilakukan oleh industri gula yang ditunjukkan dari meningkatnya pasokan tebu $1.18 \%$ dibandingkan tahun 2012. Dimensi mesin memiliki nilai sustainability index 58.67 dengan kategori berkinerja "baik". Nilai ini turun 8.28 dari nilai sustainability index tahun 2012. Hal ini disebabkan terjadi penurunan pada atribut gula yang hilang dalam proses $0.2 \%$. Dimensi ekonomi pada tahun 2013 memiliki kategori kinerja baik dengan nilai sustainability index 58.67. Nilai ini juga mengalami penurunan $12.37 \%$ dibanding tahun 2012. Penurunan ini disebabkan karena terjadi penurunan pada atribut hablur gula dan rendemen gula. Atribut hablur gula mengalami penurunan $3.14 \%$ dan rendemen gula mengalami penurunan 5,35\%. Tahap selanjutnya dilakukan analisis leverage pada dimensi material, mesin dan ekonomi untuk melihat atribut yang sensitif terhadap peningkatan nilai sustainability index.

Pada Gambar 5 terlihat bahwa atribut yang paling sensitif tahun 2013 adalah produktivitas tebu. Produktivitas tebu berpengaruh 4.69\% dalam mengubah nilai sustainability index dimensi material. Atribut jumlah tebu tidak lagi menjadi atribut yang paling sensitif karena pada tahun 2013 pasokan tebu industri telah mengalami peningkatan.

Dari Gambar 6 terlihat bahwa atribut paling sensitif pada dimensi mesin adalah usia mesin. Peningkatan atribut usia mesin dapat dilakukan dengan revitalisasi mesin pada industri gula, namun hal tersebut tidak mungkin dilakukan karena akan membutuhkan biaya tinggi, sehingga dipilih prioritas atribut kedua, yaitu kebutuhan energi. Kebutuhan energi berpengaruh 7.71\% dalam mengubah nilai sustainability index dimensi mesin. Atribut kebutuhan energi memiliki keterkaitan dengan atribut jumlah tebu pada dimensi material. Oleh karena itu, untuk mengoptimalkan kebutuhan energi pada dimensi mesin perlu dilakukan peningkatan pada atribut jumlah tebu pada dimensi material.

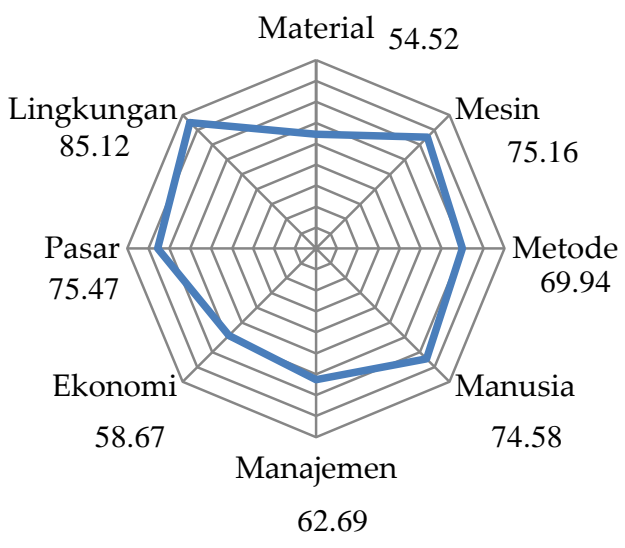

Keterangan:

Koordinat maksimum 100 (sangat baik)

Koordinat minimum 0 (buruk)

Gambar 4. Diagram layang untuk industri gula dalam penelitian ini tahun 2013

Terlihat pada Gambar 7 atribut yang paling sensitif pada dimensi ekonomi adalah hablur gula. Hablur gula berpengaruh $20.99 \%$ dalam mengubah nilai sustainability index dimensi ekonomi. Atribut hablur gula berkaitan dengan atribut mutu tebu pada dimensi material, maka peningkatan hablur gula dapat dilakukan dengan meningkatkan mutu tebu.

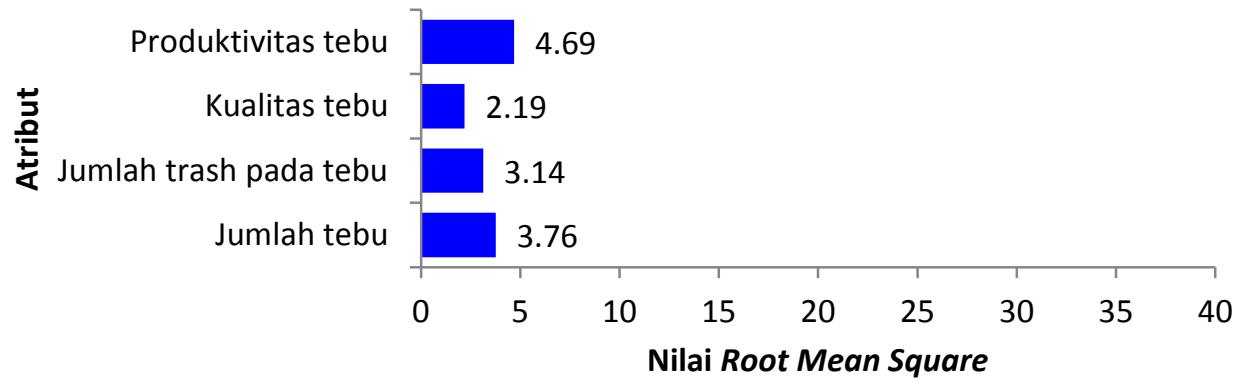

Gambar 5. Grafik analisis leverage dimensi material tahun 2013 


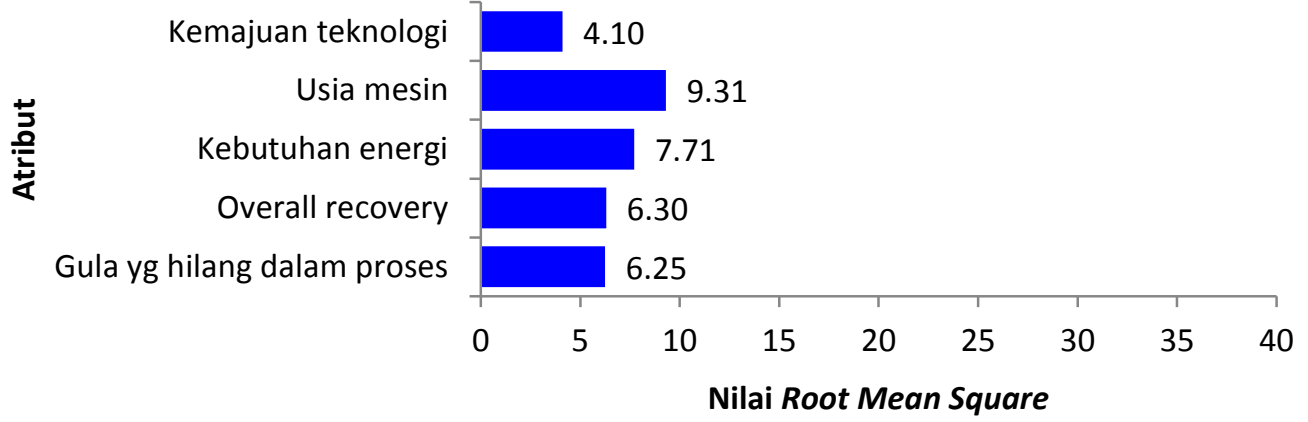

Gambar 6. Grafik analisis leverage dimensi mesin tahun 2013

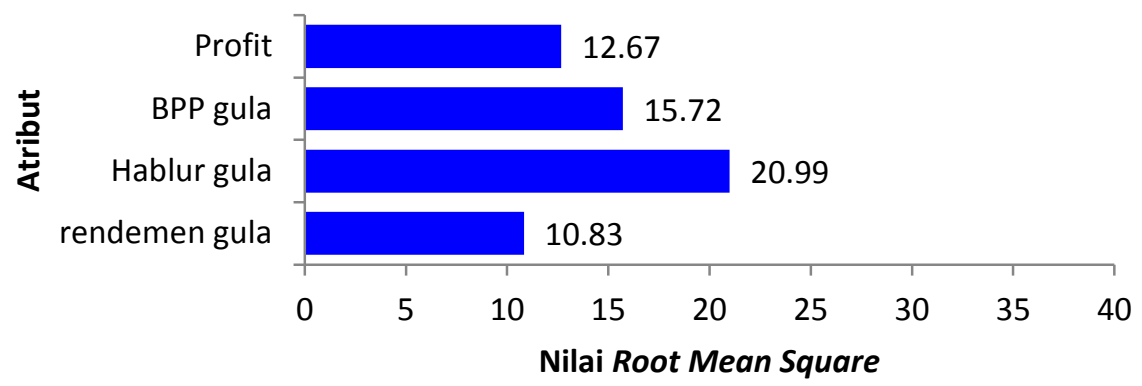

Gambar 7. Grafik analisis leverage dimensi ekonomi tahun 2013

Hasil analisis kinerja tahun 2014 dapat dilihat pada Gambar 8. Jika dibandingkan dengan tahun 2013, dimensi metode mengalami peningkatan nilai sustainability index $6.63 \%$ menjadi 75.16, sehingga terkategori berkinerja sangat baik. Hal ini dikarenakan terjadinya peningkatan pada atribut penerapan K3 dengan mulai menerapkan pemakaian helm safety. Analisis leverage pada dimensi material dan metode untuk melihat atribut yang sensitif terhadap peningkatan nilai sustainability index.

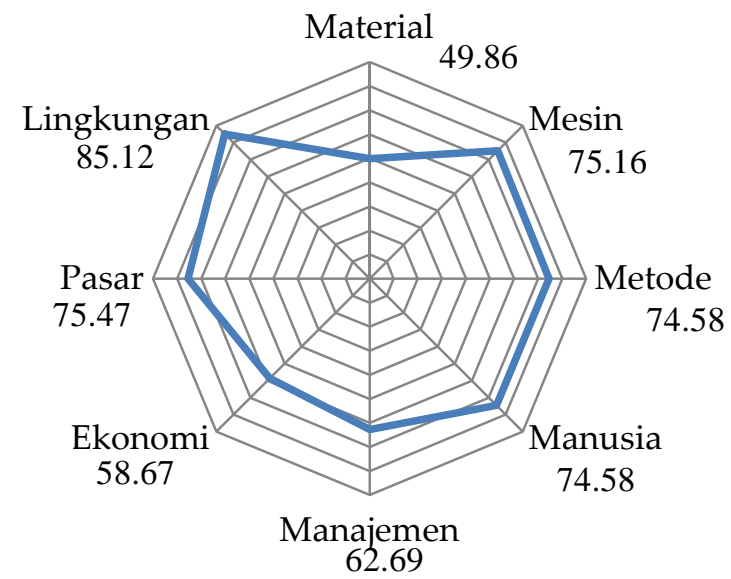

Keterangan :

Koordinat maksimum 100 (sangat baik)

Koordinat minimum (buruk)

Gambar 8. Diagram layang kinerja industri gula PT X tahun 2014
Pada Gambar 9 terlihat bahwa terdapat tiga atribut paling sensitif pada tahun 2014, yaitu perencanaan pola giling, ketersediaan infrastruktur dan kondisi infrastruktur. Untuk meningkatkan nilai sustainability index dimensi metode pada tahun 2015, diperlukan perencanaan pola giling lebih akurat untuk memperlancar produksi, ketersediaan infrastruktur yang mencukupi dan kondisi infrastruktur yang baik juga berpengaruh terhadap kelancaran produksi. Analisis leverage untuk dimensi lainnya relatif sama dengan tahun 2013, karena tidak mengalami perubahan nilai sustainability index.

Tabel 5 menunjukkan perbandingan nilai indeks keberlanjutan dari tahun 2012-2014. Dalam hal ini terlihat bahwa peningkatan atau penurunan dimensi material, mesin dan ekonomi tidak berpengaruh terhadap nilai sustainability index dimensi lainnya. Hal tersebut dikarenakan dimensi metode, manusia, pasar, manajemen, dan lingkungan tidak memiliki keterkaitan secara langsung dengan dimensi material, mesin dan ekonomi.

Berbeda dengan dimensi material yang memiliki keterkaitan dengan dimensi mesin dan ekonomi, seperti atribut mutu dan jumlah tebu yang berkaitan dengan atribut rendemen, hablur gula dan laba pada dimensi ekonomi, serta kebutuhan energi mesin dan overall recovery pada dimensi mesin. Oleh karena itu peningkatan pada dimensi material merupakan dimensi yang 


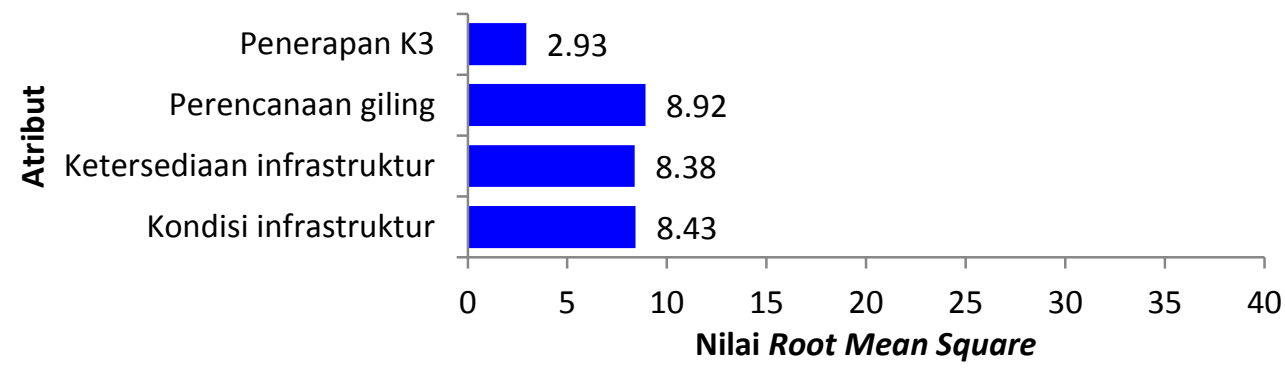

Gambar 9. Analisis leverage dimensi metode tahun 2014

memiliki nilai sustanability index terendah selama tiga tahun terakhir menjadi hal pertama yang harus dilakukan, karena juga akan berpengaruh pada peningkatan lainnya, yakni dimensi ekonomi dan mesin.

Tabel 5. Perbandingan nilai sustainability index tahun 2012, 2013 dan 2014

\begin{tabular}{lccc}
\hline \multirow{2}{*}{ Dimensi } & \multicolumn{3}{c}{ Nilai Indeks } \\
\cline { 2 - 4 } & $\mathbf{2 0 1 2}$ & $\mathbf{2 0 1 3}$ & $\mathbf{2 0 1 4}$ \\
\hline Material & 49.81 & 54.52 & 49.86 \\
Mesin & 85.64 & 75.16 & 75.16 \\
Metode & 69.94 & 69.94 & 74.58 \\
Manusia & 74.58 & 74.58 & 74.58 \\
Manajemen & 62.69 & 62.69 & 62.69 \\
Ekonomi & 66.95 & 58.67 & 58.67 \\
Pasar & 75.47 & 75.47 & 75.47 \\
Lingkungan & 85.12 & 85.12 & 85.12 \\
\hline
\end{tabular}

\section{KESIMPULAN}

Hasil pengukuran kinerja industri gula pada penelitian ini didasarkan delapan dimensi menggunakan metode multidimentional scalling menunjukkan kinerja yang baik. Hal ini terlihat dari nilai sustainability index rataan untuk setiap tahun dari tahun 2012 sampai 2014 berturutbeturut 71.27, 69.52 dan 67.87. Dimensi material yang merupakan dimensi berkinerja paling rendah. Dalam hal ini dilakukan strategi perbaikan untuk meningkatkan kinerja industri gula melalui peningkatan kinerja dengan dimensi material. Peningkatan dimensi material berdasarkan analisis leverage adalah meningkatkan mutu tebu yang dapat dilakukan dengan penyuluhan teknologi budidaya tebu pada petani, penataan varietas sesuai masa tanam, dan dukungan pemerintah dalam peningkatan penyaluran KKPE dan PMUK pada petani untuk modal program bongkar ratoon.
Penelitian ini baru mencakup kinerja industri gula di bagian off farm, padahal permasalahan utama pada industri gula sebagian besar berasal dari bagian on farm, maka dari itu saran untuk penelitian selanjutnya dalam penilaian kinerja perlu dilakukan penambahan atribut tentang aspek on farm pada dimensi material.

\section{DAFTAR PUSTAKA}

Asosiasi Gula Indonesia. 2013. Produksi Gula 2013 Lesu. [Terhubung Berkala]. http://www.asosiasigulaindonesia.org/produksi-gula2013-lesu/(Diakses 5 Agustus 2015).

Direktur Jendral Perkebunan. 2013. Program Peningkatan Produksi dan Produktivitas Gula Dalam Mewujudkan Ketahanan Pangan Nasional. Semiloka Gula Nasional 2013. Bogor. (Disampaikan pada 20 Oktober 2013).

Ernawati, L dan E. Suryani 2013. Analisis Faktor Produktivitas Gula Nasional dan Pengaruhnya terhadap harga Gula Domestik dan Permintaan Gula Impor dengan Menggunakan Sistem Dinamik. J. Teknik POMITS, 1(1): 1-7.

Kavanagh P dan TJ. Pitcher. 2004. Implementing Microsoft Excel Software for RAPFISH: A Technique for The Rapid Appraisal of Fisheries Status. Fisheries Center Research Reports 12 (2).

Nur, FY dan M. Muktiali. 2015. Pengaruh Keberadaan Industri Gula Blora terhadap Perubahan Penggunaan Lahan, Sosial Ekonomi dan Lingkungan di Desa Tinapan dan Desa Kedungwungu. Jurnal Teknik PWK, 4(3): 345-359.

Pitcher TJ dan D. Preikshot. 2001. RAPFISH: a rapid appraisal technique to evaluate the sustainability status of fisheries. Fisheries Research 49: 255-270. 
Pujitiasih, H., B. Arifin dan S. Situmorang. 2014. Analisis Posisi dan Tingkat Ketergantungan Impor Gula Kristal Rafinasi Indonesia di Pasar Internasional, JIIA, Vol 2, No 1: 32-37.
Putra, BA dan E. Suryani 2014. Skenario Kebijakan Industri Gula untuk Meningkatlan Ketersediaan Gula di Pasaran dengan Menggunakan Pendekatan Sistem Dinamik. OAJIS, vol 5, no 1 . 